Проф. др Зоран Аврамовић

Завод за унапређивање

образовања и васпитања

Београд

821.163.41.09 Андрић И. 316.75(497.6)

zoran.a@sezampro.rs https://doi.org/10.18485/ai_andric.2018.ch9

\title{
АНДРИЋ И РАЗУМЕВАЮЕ ИДЕНТИТЕТСКЕ СТВАРНОСТИ У БИХ
}

Једно од најсложенијих питања у проучавању односа књижевности и друштва тиче се сазнајне функције књижевног дела. Да ли посредством књижевноуметничког дела сазнајемо неке облике друштвене стварности и човековог положаја у њој? На ово питање се различито одговара у зависности од теоријског становишта, друштвено-политичких (историјских) околности и жанровске припадности дела. Андрићево дело је изузетно подстицајно за оваква истраживања. Да ли читање Андрићевих романа доприноси разумевању међунационалне и међуверске стварности у Босни и Херцеговини?

У раду се анализирају идентитетске сличности и разлике Срба и муслимана у роману На Дрини ћуйрија. Са завидном сазнајном прецизношћу, Андрић у роману обликује сва значења културног идентитета становника касабе на Дрини. У било ком начину читања овог романа, одмах се запажа национална и верска измешаност ликова. С једне стране, књижевним језиком се осветљавају идентитети формирани на обичајима и вери а с друге стране се указује и на утицај страног идентитета (Аустроугарска) као чиниоца промена традицијског идентитета.

Оваква сазнајна димензија романа доприноси разумевању и савремених идентитетских сличности и разлика у Босни и Херцеговини. То знање није појмовно није интуитивно, већ специфично уметничко. Сазнајна функција Андрићевог романа препознаје се посредством 
карактеризације ликова, психолошких стања, међурелигијског односа између ликова, погледа на свет.

Кључне речи: Андрић, сазнајна функција дела, идентитетске сличности и разлике.

У грађанско-међунационалном раздобљу разбијања СФРЈ (1992-1995) није био мали број страних политичара и интелектуалца који су покушавали да кроз Андрићеве романе стекну слику о Босни и Херцеговини. На првом месту њих су интересовале националне, културне, друштвене разлике међу људима у бившој југословенској републици.

Како приступити читању књижевности са, условно говорећи, некњижевног становишта? Књижевно дело је текст, скуп писаних симбола (речи). Још је Аристотел приметио да за уметност важе посебна правила. То је вештина стварања онога чега нема у природи. Она је моћ знања, осећања и маште да естетски обликује (не) посредну грађу, при чему и сам језик може послужити као грађа. Помоћу једне особене језичке конструкције, књижевност ствара уметничку илузију стварног живота човека и заједнице.

„Књижевност је друштвена установа, чији је медијум језик, друштвена творевина“ (117). То је прва реченица у поглављу „Књижевност и друштво“, у књизи Теорија књижевностии (1985) Р. Велека и О. Ворена, која нам казује једну очигледност: књижевност и језик су друштвене творевине. Питање је шта повезује књижевност и друштво? Аутори ове теорије књижевности тврде на другом месту да „књижевност није слика или сведочанство друштвене стварности“ (126). Али није нетачно да је књижевност на неки начин израз 
друштва, друштвеног живота, облика друштвености. Друштво је сложена организована целина односа и делатности, норми и вредности, а књижевност је такође сложена структура речи и значења. Нису исти жанрови романа, песме или драме као што није исто читати сатиру, реалистички роман или фантастику.

У односу између друштва и књижевности постоје бројне релације. Најпре, може се говорити само о конкретној књизи или опусу једног писца. Они који нису читали никакав утицај нису примили. Али и они који читају утицај преламају у свом читању, доживљају и знању и то споља не можемо знати: „Не можемо тачно одредити утицај једне књиге на њене читаоце“ (Велек и Ворен). Такође, у поље утицаја убацује се више посредника - изјаве писца, критичари, реклама, начин читања (Аврамовић 2017, 2016).

Књижевно знање је, за разлику од појмовног знања, по свом карактеру sui generis, односно, како закључују Велек и Ворен у књизи Теорија књижевностии (1985), то је систем норми идеалних суштина које су интерсубјективне и које се конституишу у медију литературе.

Референцијални искази у структури романа нису, наравно, сазнајне истине. Велек и Ворен тврде да „искази у једном роману, песми или драми нису дословно истинити; они нису логичке тврдње. Чак се и исказ у каквом историјском или неком Балзаковом роману - исказ који, чини се, даје 'обавештење' о стварним збивањима - битно и значајно разликује од истог обавештења у некој историјској или социолошкој књизи“(Velek i Voren 1985: 183).

Независно од ближег одређења циља науке о књижевности, које се креће у распону од објашњавања вредносног суда и тражења смисла књижевности до становишта деконструктивиста о књижевном делу као гомили 
речи где је језик систем „лутајућих знакова“, књижевно стваралаштво поседује специфично сазнајно језгро које га одваја, како од других уметничких облика, тако и од других, дискурзивних и практичних творевина.

Књижевност се у највећем броју теорија одређује као особена и непоновљива употреба језика. Суштинско обележје књижевног дела треба потражити у његовој естетској вредности. Књижевни језик карактерише, по суду Велека и Ворена, претежност естетске функције. Лепо или „постигнуће по себи“ јесте структурални елемент појма књижевности. То значи одсуство практичне сврхе из књижевног текста.

Специфичност књижевног уметничког дела огледа се и у чињеници да је књижевно стваралаштво имагинативно, односно фикционално. Књижевност расправља о измишљеним и нестварним предметима. То не значи да се свет романсијера понекад не поклапа са искуственим чињеницама, али успешна књижевност се лако препознаје по оствареној вредности кохеренције и сложености. Другим речима, књижевник може да користи животну грађу - под условом да поштује иманентну логику уметничког стварања.

Да ли постоји нешто што повезује књижевни текст и друштвену стварност? То су значења или смисао. У свакој култури језик обликује нека значења која се без обзира на употребу језика преносе и остају константна. Феномен језика је изузетно сложен. Поред графичких и фонетских особина, језик изражава богатство мисли, чулних импресија, емоционалних стања. Значење је суштинска одлика језика. Књижевно дело има одређену самосталност у односу на спољашњи или друштвени свет. Значења књижевности повезују са спољашњим светом. Речи се не могу ослободити своје мисаоности и значења у друштвеном животу и књи- 
жевном обликовању. Стварност у неком роману може бити подударна са искуственом стварношћу, под условом да књижевни текст буде схватљив „као у себи сагласна целина“ (Velek i Voren, 1985).

Како објаснити чињеницу да неко књижевно дело створено у далекој прошлости и данас изазива снажан доживљај код читаоца? У једној анкети из 2001. године, у којој су учествовали водећи светски писци (Салман Ружди, Милан Кундера, Џон Ирвинг, Карлос Фуентес), требало је да одговоре које је најбоље прозно дело на свету. Какав је био њихов одговор? По њиховом суду најбољи роман је Дон Кихоти Мигела Сервантеса, а потом следе Шескпирове драме, Хомер, Толстој, Достојевски, Кафка, Фокнер, Флобер, Гарсија Маркес, Томас Ман, Вирџинија Вулф.

Чиме то нека књижевна дела обезбеђују вечност упркос променама у економском, политичком животу, променама у свести, научном знању? Откуда то да један роман из XVI века поседује тако снажну уметничку вредност? Да ли је то универзално у локалном, специфичност једног естетичког тренутка (феномен доживљаја лепог), заједничка естетичка компонента? Велико уметничко дело је ванвремено, нешто посебно, оригинално. Оно нема граница ни у простору и времену, као што је отворено за људе различитих нација, вера, узраста, пола.

Ако књижевно дело прихвата читалац из другог времена и друге нације, то је доказ да их повезују заједнички естетски доживљај и нека универзална питања човековог постојања. То је кључни услов да би био стваралац а не знање или материјални положај. С друге стране, великог уметника не привлаче локалне теме и свакодневница. И када их обликује он је велики по томе што у њима открива нешто што је карактеристично за човека као таквог. Управо ту у значеюу, а не у сти- 
лу или поступку, треба потражити основни елеменат структуре књижевног дела који доприноси одолевању промени друштвених и књижевних епоха.

Андрићева дела припадају оној књижевности која је одолела „сусрету са заборавом“ и својом уметничком и значењском снагом припадају универзалним вредностима уметности речи.

На Дрини ћуприја - Идентитетске сличности и разлике у Босни и Херцеговини. Са завидном сазнајном прецизношћу, Андрић у свом роману обликује сва значења културног идентитета становника касабе на Дрини. У било ком начину читања овог романа, одмах се запажа национална и верска измешаност ликова. Четири века живота са вишеградском ћупријом, довела су и одвела мноштво припадника европских народа, тако да уметнички текст Иве Андрића није могао да мимоиђе питања сусретања и преплитања различитих култура.

Када се затвори последња страница романа На Дринu ћȳ̄puja (1966) читалац са наглашеним културолошким интересовањима мора се упитати о атрибутима културног идентитета касабе, о групном идентитету Срба и муслимана, о културном понашању појединих књижевних јунака. Да ли смо у прилици да посредством уметничког текста реконструишемо особеност културе Вишеграда у Андрићевом роману? Који се инструменти културног идентитета могу издвојити као сазнајно употребљиви?

Културни идентитет Срба и муслимана - сличности и разлике. У време подизања моста преко Дрине 1567-1571. становници касабе су исламизирани словенски свет (покаткад Андрић употребљава израз „вишеградски Турци“). Њихова култура је у основи усменог карактера и главни њен извор је у прошлости. „Народ лако измишља приче и брзо их шири, а стварност се чудно и неразумљиво меша и преплиће са причама. "Процес 
енкултурације српске и муслиманске деце центриран је око прича о јунацима из давних времена. За српску децу највећи јунак је био Краљевић Марко („Само, за српску децу то су трагови Шарчевих копита, остали још од онда кад је Краљевић Марко тамновао горе у Старом граду па побегао из њега, спустио се низ брдо и прескочио Дрину, на којој тада није било ћуприје“ (14). За турску децу то је био Ђерзелез Алија, јунак који је на „својој крилатој бедевији, који је као што је познато презирао скеле и скелеџије и прескакао реке као поточиће“ (14).

И поред привржености касабалијских муслимана исламу, упркос сећању на хришћанско порекло предака, у свакодневном животу вишеградске раје нема потенцирања верске припадности и односа према другом као стигме и средства властитог културног идентитета. Немали број примера солидарности становника касабе пред природном стихијом или у оружаном отпору према страној власти, потврђује да је култура свакоgневноі живойа имала снажније дејство од чинилаца културног конфликта.

У свакодневном идентитету током историје становници Вишеграда су на складан начин учествовали. Абидага, везиров повереник за подизање ћуприје уочава да и муслимани и хришћани у касаби имају сличне навике у раду и понашању - „спор и невешт у послу, али брз на подсмех и ниподаштавање“ (35). Ситуације свакодневног склада налазимо у сценама кафанског седења, чаршијских разговора, сусрета на капији ћуприје. „Најживље је у механи кад се деси да се запију варошки млађи газде и газдински синови. Тада имају посла и Сумбо и Франц Фурлан и Ћоркан и Шаха Циганка.“ (204) А са грамофона у кафани „стружу и креште турски маршеви, српске родољубиве песме и арије из бечких оперета“ (246).

Приповедање о свакодневном идентитету касабе показује како се рутинизацијом живота неутралише 
потенцијални сукоб између различитих култура. Па ипак, у роману нису изостала средства уметничког указивања на разлике у културном идентитету касабалија.

Дуговеки живот касабалија није протицао без одређених напетости између верски подељених људи. Вера је била основна стигма за обликовање разлика у културном идентитету свих становника Вишеграда а не само Срба и муслимана. Вера је имала и друга значења. Она је била покривач за све оне материјалне интересе који су својствени сваком човеку. Борба за власт и више земље, као и настојање да се свој образац живота универзализује, извирали су из темељне вододелнице-религије. „У тој великој и чудној борби која се у овој Босни вековима водила између две вере, а под видом вера за земљу и власт и своје сопствено схватање живота и уређења света, противници су отимали један другом не само жене, коње и оружје, него и песме.“ (89) Па ипак, у тој скривеној мржњи и верској нетолеранцији, суревњивости, било је „и чојства и мерхамети $а$ и осећања за ред и меру, осећања које је све те зле нагоне и грубе навике држало у сношљивим границама и, на крају, мирило их и подвргавало општим интересима заједничког живота“ (310).

Други фактор разликовања културних идентитета Срба и муслимана, Андрићев приповедач налази у оgносу према прошлости. Српска културна свест инсистира на таквој рецепцији наслеђа у коме се велича мучеништво, патња, страдање. Култ смрти (мртваца) је део културног идентитета Срба. Набијање на колац сељака Радисава за Србе у варошици није пораз, већ узвишење и победа. „Сви су осећали да је у оном сталном рвању и мерењу са Турцима сада претегло на њихову страну.“ (52) Радисав се на коцу „посветио“, ту се „издвојио и узвисио“. Труд око подмићивања Цигана зарад 
добијања мртвог тела Радисављевог и обред сахране, на уметнички начин осветљава један значајан део српског културног идентитета.

На нивоу односа према другима унуйар касабе видимо да се културни идентитети православаца и муслимана у понечем прожимају, а по неким обележјима одбијају и разликују. Та чињеница нас наводи на суд о непостојању чистог културног идентитета. Али, однос према другом појављује се још на једној равни: у односу према странцу. У српским и турским кућама није се ништа дуго мењало. „Ту се живело, радило и забављало по старом начину." (144) Долазак аустријске власти размрдава дуговеку „слатку тишину“ у касаби.

Промена културног идентитета касабе и касабалија. Живот у вишеградској варошици вековима је носио мулитикултурни печат. Није било већих и видљивих напетости између хришћана и муслимана и у такав културни амбијент лако су се уклапали сви они појединци који су имали изванвишеградску енкултурацију. Шта је могло да измени старе облике начина живота у касаби? Андрић налази кључни чинилац промене у глобалним историјским променама, а то је у његовом роману долазак аустријске власти у Босну, после Берлинског конгреса 1878. Промена мултикултурног идентитета долази споља. Судар старог и новог у Босни долази са аустријском влашћу и ту настаје једна видљива и невидљива игра прожимања и одбијања културне свести и понашања. На мосту су „се сталне и непроменљиве навике домаћег света сударале са новинама које су туђинци и њихов поредак доносили, а у тим сударима је оно што је старо и домаће било редовно осуђено на попуштање и прилагођавање“ (149).

Међутим, нови облици културе нису били имуни на утицаје затечених старих културних навика. Jе- 
дан тип шематског мишљења по правилу заборавља околност да ново не замењује брзо и лако старо и да ново такође трпи утицаје старог. Андрићев приповедач ту чињеницу добро запажа кад вели да су странци примали утицаје оријенталне културе. Ово мешање се највидљивије одигравало међу децом, у примарној енкултурацији. Преузимају се нове дечије речи и иірре.

„Њихова деца (странаца-ЗА) су доносила међу варошку децу стране изразе и туђа имена и уводила испод моста нове игре и показивала нове играчке, али су исто тако брзо примала од домаће деце наше песме, узречице и заклетве и старинске игре анџаиза, клиса и шуге.“ (188) И у процесу секундарне енкултурације странци су изазвали промене у новим речима, навикама, одевању и опхођењу у средини у којој су се нашли али нешто од начина живота староседелаца и сами су примили. Нови начин живота који је стигао са странцима, хришћани и муслимани су примали са апсолутним резервама, али су те резерве биле тајне и скривене (188). Живот је међутим био моћнији и отварао је оне путеве које нико раније није ни замишљао.

Наравно, промене које је сииранаи уносио у културни идентитет касабе изазивале су индивидуална противљења. Појединац је увек у прилици да прихвати или одбаци промену неког дела културног идентитета. У Андрићевом роману, један такав огорчени противник културних промена био је Алихоџа. Он није „прихватио ништа од новина и промена које су странци донели“ и, по казивању приповедача, то се тицало ношње, неких схватања, говора, начина трговине и пословања (223).

Долазак стране аустроугарске културе у „слатку тишину“ Босне и сучељавање два начина живота које је уследило, уводи нас у разматрање обележја мултикултурног идентитета касабе, али и у испитивање среgстиава 
културних промена. Ова два типа идентификатора нису подударна и то нам потврђује Андрићева књижевност.

Идентификатори „старог“ културног идентитета били су сличан језик и прича као окосница усмене културе. Сваки становник касабе пролази кроз примарну и секундарну енкултурацију посредством приче или митске свести. На тој основи обликују се неједнака зна-

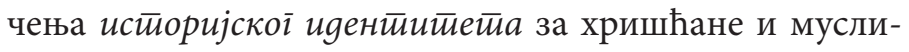
мане. Видели смо да свака заједница има своје јунаке и своје митове.

Различит је и онај део значења који се односи на будућност, тзв. пројективни идентитет. Визионарски инструмент културног идентитета индивидуализује се помоћу омладинских ликова. У том погледу карактеристичан је разговор Томе Галуса и Фехима Бахтијаревића. Српска омладина сања нову националну државу а муслиманска није рада да активистички гледа на будућност. Тома Галус заносно излаже визију нове државе која ће око Србије окупити све Јужне Словене. Таква држава носиће печат националне културе и у њој ће тријумфовати „расни геније“ са делима која нису учињена током столећа (268). Тома Галус очито стоји на становишту српског националног програма при чему није јасан његов став према другим верама и нацијама на Балкану. На све то, Фехим Бахтијаревић ћути и мисли у себи како је на крају свега све у рукама воље Божије.

Највећи степен блискости и мултикултурног склада у касаби остварује се у свакоgневном идентитету. У тој равни културног идентитета одвија се највећи део духовног, емотивног и материјалног живота касабалија. Пулсирање живота у чаршији, приче на капији ћуприје, дневне страсти малих људи, трошење времена у кафанама, све су то искуствени показатељи културне посебности. И ту су разлике најмање. 
Од материјалних обележја културног идентитета Андрићев приповедач подвлачи начин облачења ношњу. Визуелно, ношња најпре показује припадност неком културном идентитету. Муслимани носе фес, фереџу, зар, а хоџа ахмедију. За наше испитивање, карактеристичан је податак да и неки Срби носе фес. Тако стари газда Михаило „не скида свој црвени фес“ (325). Овде имамо случај мешања материјалних-симболичких индикатора културног идентитета. Капа-ношња одаје културну припадност појединца и групе. Неко ко би судио о другима по спољашњим знацима облачења, помислио би да је газда Михаило исламске вере. Са семантичке тачке гледишта овај податак нам сугерира поступак преузимања неких идентификатора националног културног идентитета у мултикултурној средини.

Други пример преузимања ношње открива нам манипулативну функцију културног идентитета. Иза једног или више индикатора могу се сакрити други идентитети. У Андрићевом роману тако нешто је учинио хајдук Јаков Чекрлија. Он је своју јатакињу Јелинку обукао у муслиманску ношњу како би преварио чуваре на мосту, Руса из источне Галиције, Грегора Федуна. Та манипулација са показатељем културне посебности, омогућила је хајдуку Јакову спас у Србију али је несрећног Руса одвела у самоубиство.

И у овом примеру налазимо неке од трагичних последица културног идентитета, које смо открили у судбини оног Италијана.

Неповољне последице културног идентитета у различитој групи (Пјетро Сола). Припадање једном културном идентитету не доноси увек сигурност. Неке историјске околности могу угрозити егзистенцију појединца или групе само због тога што ови не могу да измене своју примарну енкултурацији. У Андрићевом 
роману налазимо два таква примера: Италијан Пјетро Сола и Срби после сарајевског атентата 1914. године.

Друго трагично лице културног идентитета открива се у кривици да је неко рођен у једној култури и да је прошао кроз примарну енкултурацију свог језика. Игром живота секундарна енкултурација се наставља у другој култури све до тренутка када се терет кривице сваљује на странца, као у случају лика Пјетра Сола, само због тога што припада италијанској култури. Када су италијански анархисти убили аустријску царицу, мач невидљиве одмазде пао је на јединог Италијана у касаби, Пјетра Солу. Тај далеки чин својих сународника он је морао да одбацује премда није имао никаве везе са актерима убиства. „Кога год је срео од угледнијих и озбиљнијих људи, доказивао му је да он, иако Италијан, нема ничег заједничког са овим Лукенијем и његовим одвратним злочином.“ (218)

Оваква ситуација, тако честа у реалној историји, у Андрићевом књижевном обликовању, проширена је и на колективну кривицу због културног идентитета. После убиства аустријског војводе Фрање Фердинанда у Сарајеву 1914. године, Срби у касаби су постали сукривци за злочин који, наравно, нису учинили. У оваквим ситуацијама културни идентитет је на два начина оптерећење: они мењају своја осећања пошто је стигла вест о атентату, а жиг кривице носе у очима других становника Вишеграда. Они су се осетили у узаврелој котлини „као у клопци“. Приповедач вели да је тада „отпочела права хајка на Србе и на све што је са њима у вези“ (310). Ништа боље не одсликава страдање због културног идентитета од разговора газда Павла Ранковића и котарског предстојника, по имену Сабљак. У једном тренутку, предстојник се обраћа Ранковићу речима: „Ви сте у Сарајеву показали шта знате“ (311). Ова фамозна 
реченица, која усмерава један ток историје човечанства на трагичан начин, показује и у Андрићевом роману немогућност појединца и групе да избегну догађаје које сами не желе. Они су немоћни у настојању да одбране независност свог културног идентитета. Њихова кривица је само зато што деле исту примарну енкултурацију са онима од којих су удаљени и које не познају.

Постоји још једна последица мултикултурног сукоба. Индивидуална и групна кривица се шири и на међукултурне односе. Има догађаја који делују вулкански на једнонационалне друштвене односе а поготову на мултикултурне односе. Ту тло дуго подрхтава. Атентат у Сарајеву је у једној мирној и складној касаби изазвао за кратко време поремећај историјског културног наслеђа. „За неколико тренутака збрисана је чаршија која је почивала на вековној традицији..." (310)

Показатељи промене културног идентитета. Какви индикатори омогућавају препознавање промене културног идентитета? Промене начина живота у Андрићевом роману дешавају се у свим областима рада и мишљења. Основни индикатори промене су нови однос према раду, нова организација државне власти, нови начин одевања.

Промене које су странци унели у касабу, понајпре се тичу схватања рада. Наместо једне лежерности, спорости и нехаја, Аустријанци доносе веберовску етику рада, дакле један рационалистички однос према материјалним добрима. Касабалије се не могу начудити потреби странаца да „граде и разграђују, да копају и зидају, подижу и преиначују“ (147). Све то они раде са плановима, са неуморном радиношћу и истрајношћу у касаби такав рад изазива „чуђење и неповерење“, штавише у касаби то нико „не разуме и не цени“. Одлука нове власти да стари хан, лепу везирову задужбину поруше и подигну нову зграду - касарну, изазвала је згра- 
жање код касабалија. Они нису ни у сну помишљали да би могли „дирнути у стари хан и да би на њему требало ма шта мењати“ (148). Уместо таквог начина рада у коме се нешто планира, гради и разграђује, у вишеградској варошици се крпи и подзиђује. „Што напрсне било би закрпљено: што се нагне подупрто.“ (147)

Други показатељ промене је нова организација власти и продор политике у свакодневни живот. Одлука нових власти да изврши попис становника наишла је на незадовољство касабалија јер се тако нешто косило са њиховим схватањима и навикама. Нико у касаби није знао прави смисао тог пописа, али и начин да му се одупре (165). И почетак регрутације у Босни и Херцеговини заталасао је народ, поготову Турке. Они су се противили и султановим намерама да организује стајаћу војску.

Нови однос према раду и нова организација власти изазвала је и друге материјалне промене (спољашње). За десетак година, вели приповедач, изменила је „много штошта у спољашњем изгледу касабе, у ношњи и навикама грађана“ (221).

\section{$\mathrm{X} \times \mathrm{x}$}

Каква сазнања о културном идентитету откривамо у Андрићевом уметничком тексту На Дрини ћуйрија?

1) Нема чистог културног идентитета. Испитивање (мулти)културног идентитета Вишеграда показује да је немогућно повући линију између култура народа и вера Андрићеве Босне, а да сви показатељи буду исцрпени унутар једне културе. Видели смо да се они мешају обичајним начином или манипулативним потребама.

2) Језик није основни индикатор културног идентитета. Анализа показује да основни симболички показује у роману На Дрини ћуйрија није језик. Сви ликови лако комуницирају. Основни симболички си- 
стем који раздваја културе у Босни била је релиіија и то не толико у спољашњим обележјима колико у унутрашњим значењима у души верујућих.

3) Стабилност културног идентитета омогућава свакодневница а потенцијална конфликтност избија из историјског идентитета (прошлост и будућност). Разлике се усклађују претежно у свакодневници, тамо где је живот најнепосреднији. У тој димензији живота мултикултурни процеси се одвијају у сфери несвесног и искуственог. Свест о прошлости и будућности букне изненада и нагло се смирује. Дневни живот влада свим члановима једне заједнице.

4) Странац се у Босни појављује као фактор промене традиционалног културног идентитета. То не значи да подстицаји променама долазе и из властите културе. У Андрићевом роману је са референцијалне тачке гледишта осветљен процес промене коме је изазов једна друга култура, другачија по својој традицији и по своме духу. Чин промене нас суочава са питањем шта је идентитет? Оно што је напуштено и модификовано у културном идентитету или оно што је стечено под утицајем новог и страног? Извесно је само једно: (мулти)културни идентитет је променљива категорија у времену и простору.

\section{Литература:}

Аврамовић, Зоран. Социолочко читиане кюижевносиии. Београд: Evrobook, 2017. Штампано

Аврамовић, Зоран. Кюижевници и ӣолитика у срйској кулитури 1804-2014. Нови Сад: Православна реч, 2016. Штампано

Андрић, Иво. На Дрини ћуйрија. Београд: Просвета, 1965. Штампано

Velek, Rene i Ostin, Voren. Teorija književnosti. Beograd: Nolit, 1985. 
Zoran Avramović

\section{DO WE NEED ANDRIĆ'S WORKS FOR UNDERSTANDING SOCIAL REALITY?}

\section{Summary}

One of the most complex issues in studying the relationship between literature and society concerns the cognitive functions of literary work. Is it through literary works we find out some forms of social reality and the person's position in it? This question is answered differently, depending on the theoretical point of view, the socio-political (historical) circumstances and the genre of the work. Andric's work is extremely stimulating for such research. Does the reading of Andrićs novels contribute to understanding of the inter-ethnic and inter-religious reality in Bosnia and Herzegovina?

The paper analyzes identity similarities and differences between Serbs and Muslims in the novel $\mathrm{Na}$ Drini ćuprija. With enlightened cognitive precision, Andrić shapes all the meanings of the cultural identity of the inhabitants of the $\mathrm{ka}$ $s a b a$ on the Drina River. In any way of reading this novel, the national and religious mixture of characters is immediately observed. On the one hand, with the literary language stands out identities formed on customs and and religion, and on the other hand it points to the influence of foreign identity (Austro-Hungarian) as a factor in the change of traditional identity.

Such a sophisticated dimension of the novel contributes to the understanding of contemporary identity similarities and differences in Bosnia and Herzegovina. That knowledge is not conceptual, not intuitive, but specifically artistic. The function of Andric's novel is recognized through characterization of characters, psychological states, interreligious relationship between characters, worldview.

Key words: Andrić, the cognitive function of work, identity similarities and differences. 